\title{
Influence of Ethanol, Acidity and Chloride Concentration on the Corrosion Resistance of AISI 316L Stainless Steel
}

\author{
Elivelton A. Ferreira, ${ }^{a, b}$ Rodrigo Della Noce, ${ }^{b}$ Cecílio $S$. Fugivara ${ }^{b}$ and \\ Assis V. Benedetti ${ }^{*}, b$ \\ ${ }^{a}$ Instituto de Ciências Exatas, Universidade Federal de Alfenas, 37130-000 Alfenas-MG, Brazil \\ ${ }^{b}$ Departamento de Físico-Química, Instituto de Química, Universidade Estadual Paulista (UNESP), \\ 14801-970 Araraquara-SP, Brazil
}

\begin{abstract}
A influência do etanol, ácido sulfúrico e cloreto na resistência à corrosão do aço 316L foi investigada por meio de curvas de polarização e medidas de espectroscopia de impedância eletroquímica. No intervalo estudado, o potencial de corrosão do aço foi independente das concentrações de $\mathrm{H}_{2} \mathrm{SO}_{4}$ e $\mathrm{NaCl}$ em solução aquosa. Por outro lado, em solução contendo $65 \%$ (m/m) de etanol e $35 \%(\mathrm{~m} / \mathrm{m})$ de água, os potencias de corrosão foram mais altos do que os observados em solução aquosa. Além disso, o potencial de corrosão do aço foi alterado pela adição de $\mathrm{H}_{2} \mathrm{SO}_{4}$ e $\mathrm{NaCl}$ em solução. Em soluções com e sem etanol, mais $0,35 \%(\mathrm{~m} / \mathrm{m})$ de $\mathrm{NaCl}$, a presença de $1 \%(\mathrm{~m} / \mathrm{m})$ de $\mathrm{H}_{2} \mathrm{SO}_{4}$ inibiu o aparecimento de corrosão puntiforme.
\end{abstract}

The influence of ethanol, sulfuric acid and chloride on the corrosion resistance of $316 \mathrm{~L}$ stainless steel was investigated by means of polarization curves and electrochemical impedance spectroscopy measurements. Over the studied range, the steel corrosion potential was independent of $\mathrm{H}_{2} \mathrm{SO}_{4}$ and $\mathrm{NaCl}$ concentrations in aqueous solution. On the other hand, in solution containing 65 wt.\% ethanol and 35 wt.\% water, the corrosion potentials were higher than those obtained in aqueous solution. Besides, the steel corrosion potential was affected by the addition of $\mathrm{H}_{2} \mathrm{SO}_{4}$ and $\mathrm{NaCl}$ in solution. In solutions with and without ethanol, plus $0.35 \mathrm{wt} \% \mathrm{NaCl}$, the presence of $1 \mathrm{wt} . \% \mathrm{H}_{2} \mathrm{SO}_{4}$ inhibited the appearance of pitting corrosion.

Keywords: 316L stainless steel, electrochemical impedance spectroscopy, corrosion resistance, polarization curves

\section{Introduction}

Austenitic stainless steels were developed for use under both mild and severe corrosive conditions. Their high corrosion resistance is primarily due to the oxide layer formed on the surface, determined by the alloy composition and the environmental conditions in which the stainless steels (SS) are exposed to. ${ }^{1-4}$

Stainless steels, such as types 304 (UNS S30400) and 316 (UNS S31600), contain a variety of inclusions in the form of oxides, silicates, aluminates and sulfides. These are often present as mixed species, in which the sulfides form shells around the oxides, silicates and aluminates. The manganese sulfide shell represents a particularly favorable site for pit initiation. The dissolving shells are thought to

*e-mail: benedeti@iq.unesp.br generate crevices between the insoluble oxide-silicatealuminate cores and the stainless steel matrix, leading to appropriate conditions for the pitting propagation process..$^{5-7}$

If corrosion potential $\left(E_{\text {corr }}\right)$ is close to pitting potential $\left(E_{p}\right)$, any small change in the oxidizing power of the solution, such as the introduction of traces of oxidizers, can produce pitting by reducing the separation between $E_{\text {corr }}$ and $E_{p}$. Alloy-environment combinations that are unlikely to cause pitting will have $E_{\text {corr }}$ significantly active to $E_{p}$. The value of $E_{\text {corr }}$ of stainless steels in oxygenated chloride solution may not change considerably from alloy to alloy. The difference between $E_{p}$ or transpassivation potential, $E_{t}$ and repassivation potential, $E_{R}$ (the potential in which the film is repaired after damage) may be considered to be an indication of susceptibility to pitting corrosion of metallic materials. However, according to Sedriks, ${ }^{7}$ it has become customary to equate pitting resistance simply with 
the absolute value of $E_{p}$ rather than $E_{p}-E_{\text {corr }}$. Thus, it is generally accepted that the more noble the $E_{p}$ value, the higher the pitting resistance. ${ }^{7}$ For $316 \mathrm{~L}$ stainless steel, the $E_{p}-E_{\text {corr }}$ difference is almost constant in chloride solutions ( 0 to $5000 \mathrm{ppm}$ of $\mathrm{Cl}^{-}$ions) in the presence of oxygen at different $\mathrm{pH}(2-12) .{ }^{8}$ For this reason, it was used the $E_{p}$ values to indicate the susceptibility of this alloy to pitting corrosion.

Previous work has shown that the nitric acid passivation treatment raises the pitting potential of 316 stainless steel (316 SS) in de-aerated seawater by about $+250 \mathrm{mV} v s$. $\mathrm{Ag} / \mathrm{AgCl} / \mathrm{KCl}_{\text {sat. }}$ in the noble direction. ${ }^{9}$ Refaey et al. ${ }^{10}$ studied the corrosion of $316 \mathrm{~L} \mathrm{SS}$ in different $\mathrm{NaCl}$ concentrations ( 0.01 to $\left.2.0 \mathrm{~mol} \mathrm{~L}^{-1}\right)$, in the potential range -700 to $+2000 \mathrm{mV}$ vs. $\mathrm{Ag} / \mathrm{AgCl} / \mathrm{KCl}_{\text {sat. }}$ at a scan rate of $20 \mathrm{mV} \mathrm{s}^{-1}$. They observed that $\mathrm{NaCl}$ concentration did not affect the current $v s$. potential curves, which were characterized by the appearance of passive and transpassive regions. It was also noticed that the current increased suddenly, without any sign of oxygen evolution, indicating the breakdown of the passive layer and pitting corrosion nucleation.

Studies with 304 stainless steel in ethanolic solutions containing $0.5 \mathrm{~mol} \mathrm{~L}^{-1} \mathrm{HCl}$ and controlled amounts of water showed that no passivation occurred in the absence of water, while passivation was observed in 10 vol. $\%$ water. ${ }^{11}$ Other work $^{12}$ has shown that the passivation behavior of 304 stainless steel in ethanol/water mixtures with hydrochloric acid presents an active-passive transition, which is strongly dependent on the solution water content. Passive layers with high electronic conductivity and high resistance to cation transport (as in aqueous media) are not formed without the presence of water. ${ }^{12}$

De Anna ${ }^{13}$ studied the effects of water and chloride ions on the electrochemical behaviour of iron and 304L stainless steel in alcohols. The media studied were methyl, ethyl, isopropyl, $n$-butyl and 2-chloroethyl alcohols. The presence of water, even at a very low concentration, strongly influenced the passivation of iron in protic alcoholic solutions. The kinetics of the oxidation reactions, in the presence of water and/or chloride ions, were a function of the specific alcohol.

There has recently been an increase in ethanol demand due to its use as vehicle fuel and, as a consequence of environmental concerns, studies on the corrosion resistance of the materials used in alcohol production plants as well as in transportation and storage equipment are needed. Furthermore, studies concerning the influence of aqueous-organic solvent mixtures on $316 \mathrm{~L}$ stainless steel corrosion resistance are lacking in the literature. Our group has started a systematic study on the corrosion resistance of
$316 \mathrm{~L}$ SS in ethanolic solutions. Our lately work ${ }^{14}$ reported the evaluation of $316 \mathrm{~L} \mathrm{SS}$ corrosion resistance in a solution that simulates the acid hydrolysis of biomass. In that case, the working solution was composed of $65 \mathrm{wt} . \%$ ethanol, 35 wt. $\%$ water, 1 wt. $\% \mathrm{H}_{2} \mathrm{SO}_{4}$ and $\mathrm{NaCl}$ contents ranging from $6 \times 10^{-5}$ to $0.58 \mathrm{wt} . \%$. In this sense, our study in the present work was extended to evaluate the AISI 316L SS (UNS S31603) corrosion resistance in both ethanolic and aqueous solutions with higher chloride concentrations. Additionally, the role of $\mathrm{H}_{2} \mathrm{SO}_{4}$ content in the solutions is also studied. Therefore, this work is aimed to study the influences of ethanol, sulfuric acid and chloride on the corrosion resistance of AISI 316L stainless steel by means of potentiodynamic polarization and electrochemical impedance spectroscopy measurements.

\section{Experimental}

\section{Sample preparation}

The working electrode was a $316 \mathrm{~L}$ stainless steel (UNS S31603) provided by Dedini S/A (Piracicaba, São Paulo State, Brazil), with a nominal composition (wt.\%) of $65.85(\mathrm{Fe}), 17.56(\mathrm{Cr}), 9.44(\mathrm{Ni}), 2.29(\mathrm{Mo}), 3.94(\mathrm{Mn})$, $0.64(\mathrm{~S})$ and $0.25(\mathrm{Si})$. A geometrical area of $1 \mathrm{~cm}^{2}$, delimited by an O-ring, was exposed to the electrolyte. The electrode surface $(2 \mathrm{~cm}$ length $\times 1.5 \mathrm{~cm}$ width $\times$ $2 \mathrm{~mm}$ thickness) was progressively polished, starting with 600 and 1200 grade emery papers and finishing with a $1 \mu \mathrm{m}$ diamond suspension, using a polisher $\left(\right.$ Buehler $\left.^{\circledR}\right)$. The electrodes were then washed and sonicated with acetone, and dried using oil-free compressed air.

\section{Electrochemical cell}

All electrochemical studies were carried out in a conventional three-electrode electrochemical cell. The counter electrode was a Pt grid, and all potentials were measured against an $\mathrm{Ag} / \mathrm{AgCl} / \mathrm{KCl}_{\text {sat. }}$ reference electrode (+197 mV vs. SHE), connected to the solution via a Luggin capillary.

\section{Procedure and equipment}

Experiments were performed in aerated and unstirred $100 \mathrm{wt} . \%$ water, and a $35 \mathrm{wt} . \%$ water and $65 \mathrm{wt} . \%$ ethanol mixture, with 0.09 or $1 \mathrm{wt} . \% \mathrm{H}_{2} \mathrm{SO}_{4}$ addition, and different $\mathrm{NaCl}$ concentrations at different $\mathrm{pH}$ values (Table 1).

The solutions were prepared from analytical grade reagents and Milli-Q water quality $(18.2 \mathrm{M} \Omega \mathrm{cm})$. Polarization curves and electrochemical impedance 
Table 1. Solutions used in the corrosion study of 316L stainless steel

\begin{tabular}{lcc}
\hline Solution & medium & $\mathrm{pH}$ \\
\hline 0.35 wt. $\% \mathrm{NaCl}+$ & aqueous & 0.75 \\
1 wt. $\% \mathrm{H}_{2} \mathrm{SO}_{4}$ & 35 wt. $\% \mathrm{H}_{2} \mathrm{O}+65$ wt. $\% \mathrm{EtOH}$ & 0.95 \\
\hline 0.35 wt. $\% \mathrm{NaCl}+$ & aqueous & 1.80 \\
0.09 wt. $\% \mathrm{H}_{2} \mathrm{SO}_{4}$ & 35 wt. $\% \mathrm{H}_{2} \mathrm{O}+65$ wt. $\% \mathrm{EtOH}$ & 1.82 \\
\hline \multirow{2}{*}{0.35 wt. $\% \mathrm{NaCl}$} & aqueous & 5.03 \\
& 35 wt. $\% \mathrm{H}_{2} \mathrm{O}+65$ wt. $\% \mathrm{EtOH}$ & 5.95 \\
\hline \multirow{2}{*}{ wt. $\% \mathrm{H}_{2} \mathrm{SO}_{4}$} & aqueous & 0.96 \\
\hline \multirow{2}{*}{1.70 wt. $\% \mathrm{NaCl}^{2}$} & 35 wt. $\% \mathrm{H}_{2} \mathrm{O}+65$ wt. $\% \mathrm{EtOH}$ & 0.99 \\
\hline & aqueous & 6.00 \\
\hline
\end{tabular}

measurements were obtained using an EG\&G Model 273A potentiostat and a Solartron-SI1255 system. Before measuring the polarization curves, the electrical circuit was kept open in the different solutions for $2 \mathrm{~min}$. The anodic potential scan was then performed, at a scan rate of $0.166 \mathrm{mV} \mathrm{s}^{-1}$, starting at $+50 \mathrm{mV} v s . \mathrm{Ag} / \mathrm{AgCl} / \mathrm{KCl}_{\text {sat }}$ below the corrosion potential $\left(E_{\text {corr }}\right)$, and scanning towards positive potential, either until the appearance of localized corrosion or until the transpassive region was reached. It is very important to note that gas evolution was not observed, what means that neither oxygen nor carbon dioxide was formed. A test for the presence of acetaldehyde in the electrolyte solution before and after polarizing the electrode till $+900 \mathrm{mV}$ and $+1500 \mathrm{mV} v s$. $\mathrm{Ag} / \mathrm{AgCl} / \mathrm{KCl}_{\text {sat. }}$ was also performed using 2,4-dinitrophenylhydrazine according to the procedure previously described..$^{15}$

The electrochemical impedance spectroscopy (EIS) measurements were carried out as follows: firstly, the potential was swept towards more positive values, all located in the passive region; second, the circuit was opened and the potential measured for $1 \mathrm{~h}$; then, the impedance diagrams were recorded applying a sine wave of $10 \mathrm{mV} \mathrm{rms}$ on the corresponding open circuit potential values, $E_{o c}$. The experiments were performed in a frequency range of $100 \mathrm{kHz}$ to $5 \mathrm{mHz}$, recording 10 points per frequency decade. The electrical equivalent circuit was fitted to the experimental data using the non-linear least squares method with the software developed by Boukamp. ${ }^{16}$

Finally, in order to ensure reproducibility, a minimum of two runs were performed for each experiment.

\section{Scanning electron microscopy (SEM) analysis}

SEM micrographs of the electrode surface were taken using a scanning electron microscope (JEOL T330A and PHILIPS XL30FEG) after polarizing the electrode at different conditions.

\section{Results and Discussion}

\section{Potentiodynamic polarization curves}

Figure 1 shows the polarization curve obtained for 316L stainless steel in ethanol mixture (35 wt. $\%$ water + 65 wt. $\%$ ethanol), containing 1 wt. $\% \mathrm{H}_{2} \mathrm{SO}_{4}$ and 0.35 wt. $\%$ $\mathrm{NaCl}$, at $25^{\circ} \mathrm{C}$.

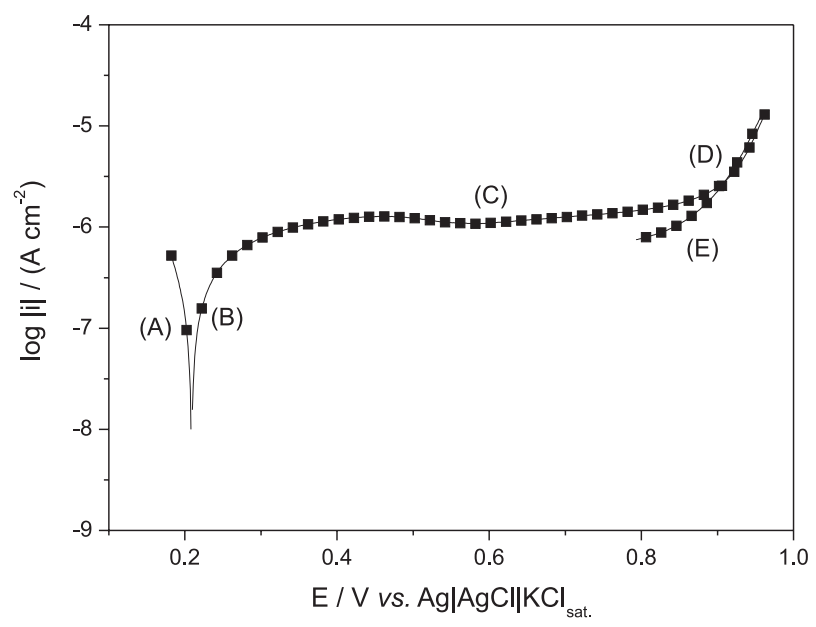

Figure 1. Polarization curve obtained at $0.166 \mathrm{mV} \mathrm{s}^{-1}$ for $316 \mathrm{~L}$ stainless steel in ethanol mixture ( $35 \mathrm{wt} . \%$ water $+65 \mathrm{wt} . \%$ ethanol), containing 1 wt. $\% \mathrm{H}_{2} \mathrm{SO}_{4}$ and 0.35 wt. $\% \mathrm{NaCl}$, at $25^{\circ} \mathrm{C}$.

The curve was divided into 5 different regions. Region A includes the cathodic part since the scan was initiated at $50 \mathrm{mV}$ below the open circuit potential, $E_{o c}$, (or corrosion potential $E_{c o r r}$ ) up to the $E_{o c}$. In this case, the change from cathodic to anodic current is directly correlated with the corrosion potential $\left(E_{\text {corr }}\right)$. In the polarization curve shown in Figure 1, this value is about $+200 \mathrm{mV} v$ s. $\mathrm{Ag} / \mathrm{AgCl} / \mathrm{KCl}_{\text {sat. }}$. Region B corresponds to the scan from the corrosion potential to the potential at which the current density practically reached a plateau. In this region, the stainless steel is oxidized and passivation was observed, and the current measured with the applied potential is due to the injection of defects in the natural oxide previously formed before starting the polarization. For even more positive potential, the current densities remained almost constant (region C). For different stainless steels, this potential region was attributed to the increase in the thickness of the oxide film formed in region B. ${ }^{17-20}$ Some works ${ }^{20-24}$ considered that the film thickness increased linearly as a function of potential, and consequently the electric field remained constant (at ca. $10^{6}-10^{7} \mathrm{~V} \mathrm{~cm}^{-1}$ ) during the film formation process. Under these conditions, the transfer of metallic cations to the electrolyte is inhibited by the presence of a passive film at the electrode surface. The current behavior in region $\mathrm{C}$ can be related to other factors: changes in the electronic 
characteristics of the film, the increase in the homogeneity of the oxide film or the decrease in defects inside the film. ${ }^{25-28}$ Considering the results obtained until now, there was no experimental support to choose one of these factors responsible for the current plateau observed in the passive region. For the SS used in the present work, the potential and current values attributed to the transition between regions $\mathrm{B}$ and $\mathrm{C}$ is close to $+0.4 \mathrm{~V}$ vs. $\mathrm{Ag} / \mathrm{AgCl} / \mathrm{KCl}_{\text {sat. }}$ and $1 \times 10^{-6} \mathrm{~mA} \mathrm{~cm}^{-2}$, respectively. At potentials higher than approximately $+850 \mathrm{mV}$ vs. $\mathrm{Ag} / \mathrm{AgCl} / \mathrm{KCl}_{\text {sat. }}$, the current density increased exponentially (region $\mathrm{D}$ ). No gas evolution was observed in this potential region, and then oxygen evolution is improbable to occur. In the same way, carbon dioxide formation in the gas form was not observed. Since the current density has almost the same values in the presence and absence of ethanol, it is little probable that ethanol oxidation is significant. In order to investigate the possible oxidation of ethanol at high positive potentials, the electrode was polarized at $+900 \mathrm{mV}$ vs. $\mathrm{Ag} / \mathrm{AgCl} / \mathrm{KCl}_{\text {sat. }}$. or at $+1500 \mathrm{mV}$ vs. $\mathrm{Ag} / \mathrm{AgCl} / \mathrm{KCl}_{\text {sat. }}$ for $30 \mathrm{~min}$ in the ethanolic solution and the electrolyte was analyzed before and after polarization by means of a reaction with 2,4-dinitrophenylhydrazine. All solutions gave negative test for the presence of acetaldehyde. Considering that no gas evolution $\left(\mathrm{CO}_{2}\right)$ was observed and that the presence of acetaldehyde was not detected, it was concluded that the oxidation of ethanol, if occurs under these conditions, is of low significance and can be neglected.

In order to determine whether the increase in the current density in region D was associated with steel transpassivation, or it was due to localized corrosion, the potential scan was inverted (region E). In general, the transpassive region is characterized by a rapid process of passivation/metal dissolution at positive potentials, which is usually considered as a type of damage of the passivated metal. ${ }^{29}$ Transpassivation is a phenomenon that a passive metal starts rapid dissolution if the electrode potential becomes too positive. It is believed that transpassivation is a process in which some chemical species in the original passive film turning into higher valence and more soluble products. As transpassivation is a rapid dissolution process, it is generally regarded as a type of corrosion damage to a passivated metal. ${ }^{29}$

The potential inversion can provide information about the feasibility of repairing the damaged film. Current density values higher than those obtained in the direct scan (before inverting the scan) indicate that the damaged passive film is not repaired and/or localized corrosion has started, while smaller current values reflect film repair under the same conditions, and therefore the pitting process (stable pit formation) is not initiated. ${ }^{14}$ As can be seen in Figure 1, in the reverse scan, the current density decreased exponentially as the potential decreased, indicating that the current density increase in the direct scan was not associated with the localized corrosion, but with transpassivation of the steel.

In the potential range of the polarization curve, no oxygen evolution was observed. Studies carried out in our laboratory with $316 \mathrm{~L}$ stainless steel in ethanolic solutions containing 65 wt. $\%$ ethanol, 35 wt.\% water and $1 \mathrm{wt} \% \mathrm{H}_{2} \mathrm{SO}_{4}$ showed that no oxygen evolution occurred up to $2000 \mathrm{mV}$ vs. $\mathrm{Ag} / \mathrm{AgCl} / \mathrm{KCl}_{\text {sat. }}$, and therefore it was concluded that the transpassivation region (about +900 to $+2000 \mathrm{mV}$ vs. $\mathrm{Ag} / \mathrm{AgCl} / \mathrm{KCl}_{\text {sat. }}$ ) is not affected by the oxygen reaction. ${ }^{14}$ Current density $v s$. potential profiles with similar regions to those shown in Figure 1 were obtained in corrosion resistance studies of passive films on 216L and 316L stainless steels in $1 \mathrm{~mol} \mathrm{~L}^{-1} \mathrm{H}_{2} \mathrm{SO}_{4}$, in the presence of different $\mathrm{NaCl}$ concentrations, ${ }^{30}$ and for $304 \mathrm{~L} \mathrm{SS}$ in aqueous solution containing $0.05 \mathrm{~mol} \mathrm{~L}^{-1} \mathrm{H}_{2} \mathrm{SO}_{4}$ and $0.05 \mathrm{~mol} \mathrm{~L}^{-1}$ $\mathrm{NaCl}{ }^{31}$

Figures 2a, 2b, and 2c show the SEM micrographs for the polarized steel in the absence and presence of ethanol, respectively. According to X-ray microanalysis previously performed, ${ }^{14}$ both images show MnS inclusion dissolution up to the transpassivation region $(+1000 \mathrm{mV}$ and $+1500 \mathrm{mV} v s$. $\mathrm{Ag} / \mathrm{AgCl} / \mathrm{KCl}_{\text {sat. }}$ ). Rounded holes can be seen on the electrode surface which do not correspond to stable pit formation. In solutions containing $0.35 \mathrm{wt} . \% \mathrm{NaCl}$ and low $\mathrm{H}_{2} \mathrm{SO}_{4}$ concentration ( $<1$ wt. $\%$ ), pitting corrosion was observed. Figures 3 shows cyclic polarization curves obtained in solutions comprising zero and 0.09 wt.\% $\mathrm{H}_{2} \mathrm{SO}_{4}$ in aqueous and ethanolic solutions, respectively. In both curves a sharp increase of current density was observed for potentials around +400 and $+500 \mathrm{mV}$ vs. $\mathrm{Ag} / \mathrm{AgCl} / \mathrm{KCl}_{\text {sat. }}$. (Table 2), respectively, suggesting localized corrosion, while no stable pits were observed with $1.0 \mathrm{wt} . \% \mathrm{H}_{2} \mathrm{SO}_{4}$ (Figure 1). Figures $4 \mathrm{a}$ and $4 \mathrm{~b}$ depict SEM micrographs of the electrode surfaces where pits are observed, confirming the suggestion given by polarization curves.

Brooks et al. ${ }^{32}$ reported the incorporation of sulfate and chromate in the oxide film grown on stainless steel during anodic oxidation in sulfuric acid, and concluded that the incorporation of these anions impeded the ingress of chloride ions into the film. As a consequence of the incorporation of these anions, a coulombic barrier against chloride adsorption is formed, which leads to a high resistance to stable pit formation. ${ }^{33}$ In the present work, the anodic oxidation of stainless steel with $1 \mathrm{wt} . \% \mathrm{H}_{2} \mathrm{SO}_{4}$ might have occurred similarly to the literature. ${ }^{32,33}$

In an ethanol/water mixture, the maximum amount of $\mathrm{NaCl}$ that can be solubilized is close to $2.0 \mathrm{wt} . \%,{ }^{34}$ hence in the electrochemical measurements $1.70 \mathrm{wt} . \% \mathrm{NaCl}$ was 

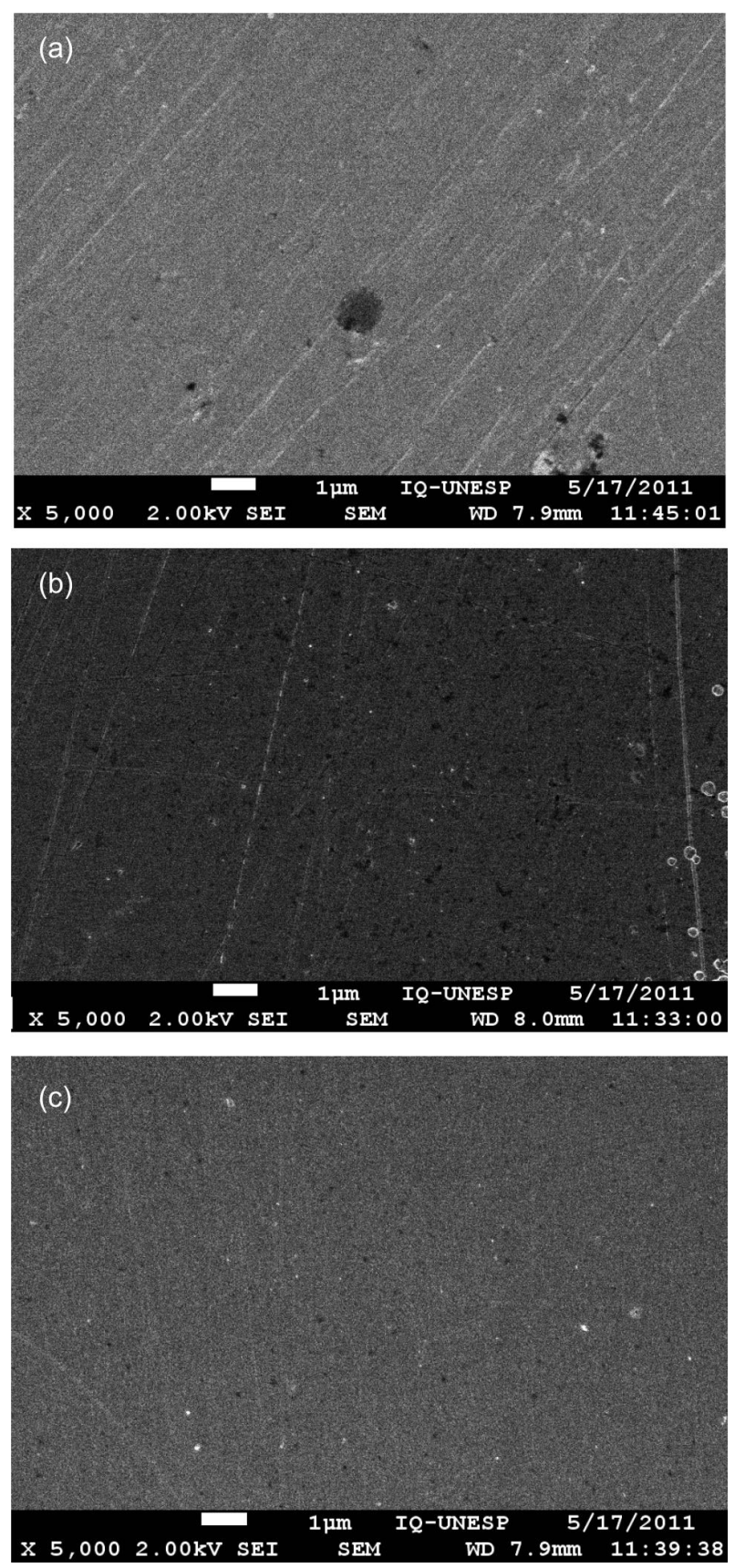

Figure 2. SEM micrographs of $316 \mathrm{~L}$ stainless steel after polarizing in aqueous solution up to $1000 \mathrm{mV} v s$. $\mathrm{Ag} / \mathrm{AgCl} / \mathrm{KCl}_{\text {sat. }}$ (a) and in ethanol mixture (35 wt.\% water $+65 \mathrm{wt} . \%$ ethanol) up to $1000 \mathrm{mV} v s$. $\mathrm{Ag} / \mathrm{AgCl} / \mathrm{KCl}_{\text {sat. }}$ (b) and ca. $1500 \mathrm{mV}$ vs. $\mathrm{Ag} / \mathrm{AgCl} / \mathrm{KCl}_{\text {sat. }}$ (c), all solutions containing 1 wt. $\% \mathrm{H}_{2} \mathrm{SO}_{4}$ and 0.35 wt. $\% \mathrm{NaCl}$, at $25^{\circ} \mathrm{C}$.

added to ensure complete salt dissolution (Table 2). No $\mathrm{H}_{2} \mathrm{SO}_{4}$ was added since $1 \mathrm{wt} . \%$ of acid decreases the salt solubility in an ethanol/water/ $\mathrm{NaCl}$ mixture. By adding 1.70 wt. $\% \mathrm{NaCl}$ to the solution, no ethanol influence was observed in the pitting potential (Table 2). Independently of the employed medium, it can be noted (Table 2) that the pitting potential decreased as the $\mathrm{NaCl}$ concentration increased from 0.35 to $1.70 \mathrm{wt} . \%$, and the magnitude of

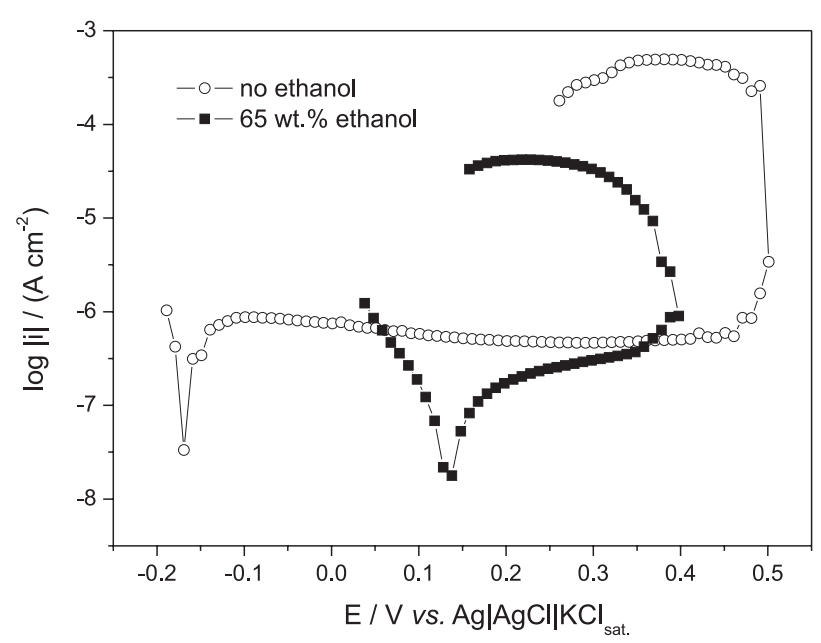

Figure 3. Polarization curve obtained at $0.166 \mathrm{mV} \mathrm{s}^{-1}$ for $316 \mathrm{~L}$ stainless steel recorded in aqueous solution and in ethanol mixture ( $35 \mathrm{wt} . \%$ water + 65 wt. $\%$ ethanol) +0.09 wt. $\% \mathrm{H}_{2} \mathrm{SO}_{4}$, both containing $0.35 \mathrm{wt} . \% \mathrm{NaCl}$, at $25^{\circ} \mathrm{C}$.

the pitting potential decrease also depends on the presence of sulfuric acid. Finally, stainless steel-environment combinations that are unlikely to cause pitting will have $E_{c o r r}$ significantly active to $E_{p}\left(E_{c o r r}<<E_{p}\right)$ or transpassive potential $\left(E_{t}\right)$ and only general corrosion commonly occurs. ${ }^{7}$ This behavior was observed for the solutions without chloride ions and with 0.35 wt. $\% \mathrm{NaCl}+1$ wt. $\% \mathrm{H}_{2} \mathrm{SO}_{4}$ (Table 2).

\section{Electrochemical impedance spectroscopy measurements}

EIS measurements were carried out in order to determine the influence of the solution in the characteristics of the passive film potentiodynamically formed at $0.166 \mathrm{mV} \mathrm{s}^{-1}$. The potential scanning was performed from the open circuit potential $\left(E_{c o r r}\right)$ to three different final potentials $\left(E_{\mathrm{f}}\right)$ associated with steel passivation (Table 2), $\left(E_{f}-E_{\text {corr }}\right.$ was named overpotential from now on), hence avoiding occurrence of pitting or transpassivation (Table 3). The circuit was open and the potential measured for $1 \mathrm{~h}$. The EIS diagrams were then obtained by applying the ac signal on that open circuit potential obtained after the polarization using six solutions, being three with ethanol.

The variation of the open circuit potential after pontentiodynamic polarization in the solutions with and without ethanol was related to differences in viscosity, density and dielectric constant, and possibly to the thickness of the films.

Figure 5 displays the experimental and fitted complex plane (Figure 5a) and Bode (Figure 5b) plots for 316L stainless steel, obtained in aqueous solution and in the 35 wt. $\%$ water and 65 wt. $\%$ ethanol mixture, both containing 1 wt. $\% \mathrm{H}_{2} \mathrm{SO}_{4}$ plus 0.35 wt. $\% \mathrm{NaCl}$, at $25{ }^{\circ} \mathrm{C}$. 
Table 2. Parameters for $316 \mathrm{~L}$ stainless steel obtained from polarization curves in aqueous and ethanolic solutions at $25^{\circ} \mathrm{C}$

\begin{tabular}{|c|c|c|c|c|}
\hline Solution & medium & $E_{\text {corr }} / \mathrm{mV}$ & $E_{\mathrm{p}} / \mathrm{mV}$ & $E_{\text {trans }} / \mathrm{mV}$ \\
\hline \multirow{2}{*}{0.35 wt. $\% \mathrm{NaCl}+1$ wt. $\% \mathrm{H}_{2} \mathrm{SO}_{4}$} & aqueous & $-173 \pm 66$ & - & +890 \\
\hline & 35 wt. $\% \mathrm{H}_{2} \mathrm{O}+65$ wt. $\%$ EtOH & $+204 \pm 6$ & - & $+876 \pm 8$ \\
\hline \multirow{2}{*}{0.35 wt. $\% \mathrm{NaCl}+0.09$ wt. $\% \mathrm{H}_{2} \mathrm{SO}_{4}$} & aqueous & $-180 \pm 19$ & $+516 \pm 30$ & \\
\hline & 35 wt. $\% \mathrm{H}_{2} \mathrm{O}+65$ wt. $\%$ EtOH & $+50 \pm 45$ & $+395 \pm 25$ & \\
\hline \multirow{2}{*}{0.35 wt. $\% \mathrm{NaCl}$} & aqueous & $-159 \pm 13$ & $+419 \pm 56$ & - \\
\hline & 35 wt. $\% \mathrm{H}_{2} \mathrm{O}+65$ wt. $\%$ EtOH & $+117 \pm 21$ & $+434 \pm 71$ & - \\
\hline \multirow{2}{*}{1 wt. $\% \mathrm{H}_{2} \mathrm{SO}_{4}$} & aqueous & $-158 \pm 28$ & - & +900 \\
\hline & 35 wt. $\% \mathrm{H}_{2} \mathrm{O}+65$ wt. $\%$ EtOH & $+180 \pm 74$ & - & +874 \\
\hline \multirow{2}{*}{1.70 wt. $\% \mathrm{NaCl}$} & aqueous & $-145 \pm 34$ & $+271 \pm 92$ & - \\
\hline & 35 wt. $\% \mathrm{H}_{2} \mathrm{O}+65$ wt. $\%$ EtOH & $-91 \pm 23$ & $+266 \pm 66$ & - \\
\hline
\end{tabular}

In these solutions, the oxide films were grown up to $+600 \mathrm{mV} v s . \mathrm{Ag} / \mathrm{AgCl} / \mathrm{KCl}_{\text {sat. }}$, at $0.166 \mathrm{mV} \mathrm{s}^{-1}$, and before
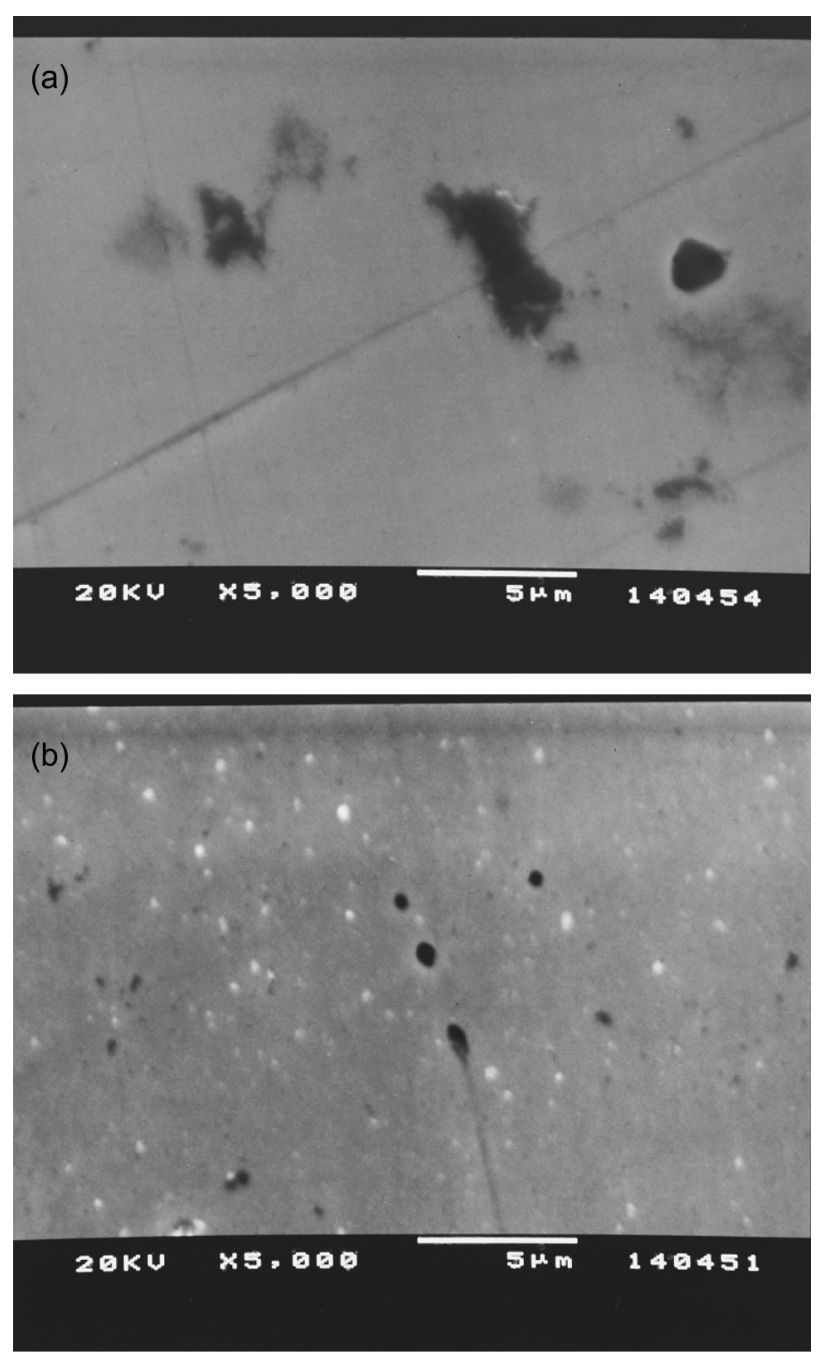

Figure 4. SEM micrographs of 316L stainless steel after polarizing up to the pitting corrosion region in aqueous solution (a) and in ethanol mixture ( $35 \mathrm{wt} . \%$ water $+65 \mathrm{wt} . \%$ ethanol) $+0.09 \mathrm{wt} . \% \mathrm{H}_{2} \mathrm{SO}_{4}$ (b), both containing 0.35 wt. $\% \mathrm{NaCl}$, at $25^{\circ} \mathrm{C}$. starting the experiments, the sample was held at open circuit potential for $1 \mathrm{~h}$.
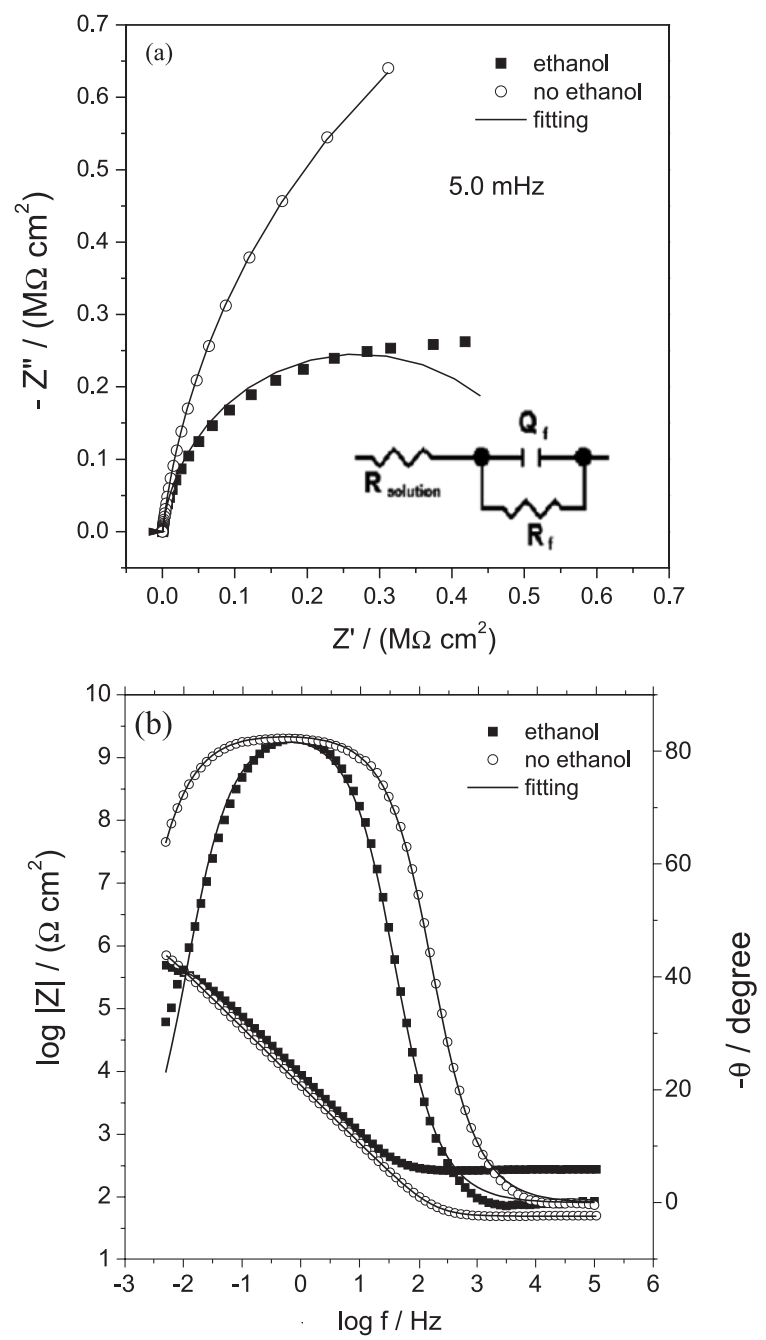

Figure 5. Experimental and fitted complex plane (a) and Bode (b) plots for $316 \mathrm{~L}$ stainless steel obtained in aqueous solution and in a mixture of $35 \mathrm{wt} . \%$ water and $65 \mathrm{wt} . \%$ ethanol, both containing $1 \mathrm{wt} . \% \mathrm{H}_{2} \mathrm{SO}_{4}$ plus 0.35 wt. $\% \mathrm{NaCl}$, at $25{ }^{\circ} \mathrm{C}$. 
Table 3. Selected $E_{\mathrm{f}}$ values and solutions, open circuit potentials applied for EIS measurements, and circuit element parameters (shown in Figure 5b) obtained from the adjustment of their responses to the experimental impedance data

\begin{tabular}{|c|c|c|c|c|c|c|c|c|}
\hline Solution & medium & $\begin{array}{l}E_{\mathrm{f}} / \\
\mathrm{mV}\end{array}$ & $\begin{array}{l}E_{\mathrm{OC}} / \\
\mathrm{mV}^{\mathrm{a}}\end{array}$ & $\begin{array}{c}R_{\mathrm{s}} / \\
\left(\Omega \mathrm{cm}^{2}\right)\end{array}$ & $\begin{array}{c}R_{f} / \\
\left(\mathrm{M} \Omega \mathrm{cm}^{2}\right)\end{array}$ & $\begin{array}{c}Q_{f} / \\
\left(\mu \mathrm{F} \mathrm{cm}^{-2} \mathrm{~s}^{n-1}\right)\end{array}$ & $N$ & $\chi^{2}$ \\
\hline \multirow{2}{*}{0.35 wt. $\% \mathrm{NaCl}+1$ wt. $\% \mathrm{H}_{2} \mathrm{SO}_{4}$} & aqueous & +600 & +140 & $\begin{array}{c}49.5 \\
(0.3 \%)\end{array}$ & $\begin{array}{c}2.1 \\
(2.6 \%)\end{array}$ & $\begin{array}{c}31.3 \\
(0.2 \%)\end{array}$ & $\begin{array}{c}0.9 \\
(0.1 \%)\end{array}$ & $2.1 \times 10^{-4}$ \\
\hline & 35 wt. $\% \mathrm{H}_{2} \mathrm{O}+65$ wt. $\% \mathrm{EtOH}$ & +600 & +300 & $\begin{array}{c}266.8 \\
(0.8 \%)\end{array}$ & $\begin{array}{c}0.5 \\
(2.2 \%)\end{array}$ & $\begin{array}{c}21.1 \\
(0.9 \%)\end{array}$ & $\begin{array}{c}0.9 \\
(0.3 \%)\end{array}$ & $1.9 \times 10^{-3}$ \\
\hline \multirow{2}{*}{0.35 wt. $\% \mathrm{NaCl}$} & aqueous & +300 & -14 & $\begin{array}{l}371.2 \\
(1.4)\end{array}$ & $\begin{array}{c}0.8 \\
(4.4 \%)\end{array}$ & $\begin{array}{c}18.5 \\
(1.5 \%)\end{array}$ & $\begin{array}{c}0.9 \\
(0.5 \%)\end{array}$ & $6.4 \times 10^{-3}$ \\
\hline & 35 wt. $\% \mathrm{H}_{2} \mathrm{O}+65$ wt. $\% \mathrm{EtOH}$ & +300 & +202 & $\begin{array}{l}1480.5 \\
(1.2 \%)\end{array}$ & $\begin{array}{c}0.8 \\
(4.0 \%)\end{array}$ & $\begin{array}{c}12.6 \\
(1.5 \%)\end{array}$ & $\begin{array}{c}0.9 \\
(0.6 \%)\end{array}$ & $5.3 \times 10^{-3}$ \\
\hline \multirow{2}{*}{1.70 wt. $\% \mathrm{NaCl}$} & aqueous & +200 & -54 & $\begin{array}{c}75.2 \\
(1.3 \%)\end{array}$ & $\begin{array}{c}0.4 \\
(2.8 \%)\end{array}$ & $\begin{array}{c}23.4 \\
(1.3 \%)\end{array}$ & $\begin{array}{c}0.9 \\
(0.4 \%)\end{array}$ & $4.3 \times 10^{-3}$ \\
\hline & 35 wt. $\% \mathrm{H}_{2} \mathrm{O}+65$ wt. $\%$ EtOH & +200 & -68 & $\begin{array}{c}299.0 \\
(0.8 \%)\end{array}$ & $\begin{array}{c}0.4 \\
(2.4 \%)\end{array}$ & $\begin{array}{c}28.7 \\
(0.9 \%)\end{array}$ & $\begin{array}{c}0.9 \\
(0.3 \%)\end{array}$ & $1.9 \times 10^{-3}$ \\
\hline
\end{tabular}

aEIS measurements were obtained polarizing the electrode at these potentials, the $E_{O C}$ after polarization.

A simple and incomplete semi-circle in the complex plane plot is clearly seen, and similar impedance diagrams were recorded for all other conditions and studied solutions. According to Park et al. ${ }^{35}$ in impedance experiments, a simple semi-circle corresponds to a charge transfer reaction by means of ionic migration through the passive oxide film. The Bode plots show only one time constant with a phase angle around $-80^{\circ}$ that can be attributed to the oxide film on steel (Figure 5b). The presence of only one time constant in Bode plots was also found by Wallinder et al ${ }^{31}$ for $304 \mathrm{~L}$ stainless steel in aqueous solution containing $0.05 \mathrm{~mol} \mathrm{~L}^{-1}$ $\mathrm{H}_{2} \mathrm{SO}_{4}$ and $0.05 \mathrm{~mol} \mathrm{~L}^{-1} \mathrm{NaCl}$, after exposing the sample for $90 \mathrm{~min}$ at open circuit potential and polarizing the electrode by applying the open circuit potential. Park et al. ${ }^{35}$ obtained similar results for 316L stainless steel in aqueous solution containing $0.5 \mathrm{~mol} \mathrm{~L}^{-1} \mathrm{NaCl}$ and $0.5 \mathrm{~mol} \mathrm{~L}^{-1} \mathrm{NaHCO}_{3}$, applying different anodic potentials.

The electrical equivalent circuit (EEC, see Figure 5a) was fitted to the experimental data. ${ }^{16}$ The sum of square deviations $\left(\chi^{2}\right)$ around $10^{-3}$, the low errors $(\%)$ associated with estimation of all the parameters (Table 3), and the good adjustment between the fitted and the experimental diagrams indicate the adequacy of the proposed EEC. The deviation between experimental and adjusted impedance data in Figure 5a in the presence of ethanol observed at low frequency is not clear yet. EEC consists of a constant phase element (CPE) that is composed by a term which is related to the capacitance of the passive film, $Q_{f}$, and $n$ the exponent. The heterogeneity of the studied systems leads to non-ideal capacitive responses, thus the so-called constant phase element substitutes the capacitance. ${ }^{36} \mathrm{CPE}$ is in parallel with the polarization resistance, essentially the resistance of the oxide film. The $R_{f}$ was attributed to the ionic migration inside the film and is in series with the solution resistance, $R_{\text {solution }}$.

The resistances of the solutions are influenced by their viscosities, densities, dielectric constants and conductivities. Table 3 shows that the solution containing $0.35 \mathrm{wt} . \% \mathrm{NaCl}$ plus $1 \mathrm{wt} . \%$ sulfuric acid presented higher conductivity than the solution without sulfuric acid, and the conductivity was lower when ethanol was present. Also, the solution containing $1.7 \mathrm{wt} . \% \mathrm{NaCl}$ exhibited higher conductivity than the one with $0.35 \mathrm{wt} . \% \mathrm{NaCl}$. Then, it is clear that the presence of ethanol increased the resistivity of all solutions. The values of $R_{f}$ and $Q_{f}$ present slightly influence of the electrolyte which means that the characteristics of the oxide film, reflected in the impedance diagrams, are practically independent of the $E_{\mathrm{f}}$ values. The $n$ values are 0.9 and the phase angle values suggest a near-capacitor behavior. ${ }^{14}$

Table 4 shows the calculated capacitance and the thickness of the oxide films obtained from the frequency at the maximum imaginary impedance which was estimated from the EEC according to equations 1 and $2 .{ }^{37}$

$C=Q\left(\omega_{\max }\right)^{\mathrm{n}-1}$

$L=\varepsilon_{0} \varepsilon / C$

where $C$ corresponds to the interfacial capacitance, $Q$ is attributed to the CPE parameter of the interfacial capacitance, $\mathrm{n}$ is the exponent, $\omega_{\max }$ is the characteristic frequency at which the imaginary part of impedance reaches its maximum magnitude, $L$ is the thickness of the oxide film, $\varepsilon_{0}$ is the vacuum permittivity $\left(8.854 \times 10^{-14} \mathrm{~F} \mathrm{~cm}^{-1}\right)$ and $\varepsilon$ is equal to 12 which is the relative dielectric constant of the iron oxide. ${ }^{38,39}$ 
Table 4. Capacitance values and estimated oxide thickness calculated from equation 1 and 2 for the aqueous and ethanolic solutions studied in this work at $25^{\circ} \mathrm{C}$

\begin{tabular}{|c|c|c|c|}
\hline Solution & medium & $C_{\mathrm{f}} /\left(\mu \mathrm{F} \mathrm{cm}^{-2}\right)$ & $L / \mathrm{nm}$ \\
\hline \multirow[t]{2}{*}{0.35 wt. $\% \mathrm{NaCl}+1$ wt. $\% \mathrm{H}_{2} \mathrm{SO}_{4}$} & aqueous & 45.2 & 23 \\
\hline & 35 wt. $\% \mathrm{H}_{2} \mathrm{O}+65$ wt. $\% \mathrm{EtOH}$ & 31.9 & 33 \\
\hline \multirow[t]{2}{*}{0.35 wt. $\% \mathrm{NaCl}$} & aqueous & 29.3 & 36 \\
\hline & 35 wt. $\% \mathrm{H}_{2} \mathrm{O}+65$ wt. $\%$ EtOH & 19.1 & 56 \\
\hline \multirow[t]{2}{*}{1.70 wt. $\% \mathrm{NaCl}$} & aqueous & 35.4 & 30 \\
\hline & 35 wt. $\% \mathrm{H}_{2} \mathrm{O}+65$ wt. $\%$ EtOH & 44.5 & 24 \\
\hline
\end{tabular}

Before discussing the data presented in Table 4, some explanations are needed. It is probably that both the capacitance of the oxide film and the electrical double layer are influencing the $\operatorname{CPE~}\left(Q_{f}\right.$ and $\left.n\right)$ values obtained, mainly if they are similar in magnitude. Then, as both are in series, to have the capacitance of the oxide film only it must be much lower than the electrical double layer capacitance. ${ }^{27}$ Therefore, it means that the corresponding thickness estimated from the capacitance values (Table 4) may be not realistic. Also, it is important to note that the anodic potential limits during electrode polarization were chosen to represent a condition in which no pitting or transpassivation phenomena occur. For instance, in the presence of sulfuric acid and $0.35 \mathrm{wt} . \% \mathrm{NaCl}$, the film was formed by potential sweeping from the $E_{\text {corr }}$ value (Table 2) to $+600 \mathrm{mV}$ considering that no pitting attack was observed. The transpassive potential is higher than $+600 \mathrm{mV} v s . \mathrm{Ag} / \mathrm{AgCl} / \mathrm{KCl}_{\text {sat. }}$ and almost the same in the presence and absence of ethanol. Hence, the same anodic potential limit was applied when ethanol was added to the aqueous solution. However, even considering that the same final potential was applied, the overpotential $\left(E_{f}-E_{c o r r}\right)$ was different for these two solutions, being higher for aqueous solution, which may result in a thicker film. Thus, a thinner film should be expected for the solution containing ethanol, which cannot be seen in Table 4. Also, it is possible that the electrical double layer is influencing the $C$ value, which could occur if large quantity of defects is present in the oxide film. ${ }^{40}$

For the other solutions (Table 2), pitting attack was observed, and then, the anodic polarization was limited to a potential around $0.1 \mathrm{~V}$ lower than the pitting potential. The anodic potential limits in which +300 and $+200 \mathrm{mV}$, respectively for the solutions with 0.35 and $1.70 \mathrm{wt} . \%$ $\mathrm{NaCl}$ without sulfuric acid. For the solution with $0.35 \mathrm{wt} . \%$ $\mathrm{NaCl}$, the capacitance value in the presence of ethanol led to the formation of a thicker film than in its absence, and no significant influence of ethanol was observed in the solution with $1.7 \mathrm{wt} . \% \mathrm{NaCl}$. In the last solution, the overpotential in the absence and presence of ethanol was almost the same, around $+300 \mathrm{mV}$.

Electrochemical and X-ray photoelectron spectroscopy (XPS) studies of passive films formed on stainless steel in solutions containing borate buffer and chloride showed that film composition is dependent on its thickness and the electrolyte. ${ }^{41}$ Thus, the oxide films formed on $316 \mathrm{~L}$ stainless steel immersed in different electrolytes may have different compositions, as well as thickness, and consequently different electrical properties.

\section{Conclusions}

In conclusion, the influence of ethanol, acidity and chloride concentration on the corrosion resistance of AISI $316 \mathrm{~L}$ stainless steel was investigated by means of polarization curves and electrochemical impedance spectroscopy. The electrochemical results evidenced the presence of an oxide layer onto the 316L stainless steel (316 SS) which in conjunction with pitting potential values ensures the corrosion resistance of this kind of SS in different media (ethanolic and aqueous solutions) at room temperature. Independently of the employed media, it was found that pitting potential decreased as the $\mathrm{NaCl}$ concentration increased, from ca. $+400 \mathrm{mV} v$ s. $\mathrm{Ag} / \mathrm{AgCl} / \mathrm{KCl}_{\text {sat. }}(0.35 \mathrm{wt} . \% \mathrm{NaCl})$ to approximately $+250 \mathrm{mV}$ vs. $\mathrm{Ag} / \mathrm{AgCl} / \mathrm{KCl}_{\text {sat }}$. $(1.70$ wt. $\% \mathrm{NaCl})$. In both solutions, with and without ethanol, plus 0.35 wt. $\% \mathrm{NaCl}$, the presence of $1 \mathrm{wt} . \% \mathrm{H}_{2} \mathrm{SO}_{4}$ inhibited the appearance of pitting corrosion at $25^{\circ} \mathrm{C}$.

The electrical equivalent circuit adjusted for the impedance data was $\left(R_{\text {solution }}\left[R_{f} Q_{f}\right]\right)$, which consists of a CPE in parallel with the polarization resistance, being in series with the solution resistance, $R_{\text {solution }}$. CPE is composed by a term related to the capacitance of the passive film, $Q_{f}$, and $n$ the exponent. The $R_{f}$ was attributed to the ionic migration inside the film, essentially the resistance of the oxide film. Based on the $Q_{f}$ value the capacitance of the film, $C_{f}$ was calculated, which allowed estimating the oxide film thickness. 


\section{Acknowledgements}

The authors gratefully acknowledge financial support and scholarships from the Brazilian funding agencies FAPESP (proc. No. 2008/50579-7) and CNPq (proc. Nos. 305890/2010-7 and 150729/2011-1).

\section{References}

1. Pardo, A.; Merino, M. C.; Coy, A. E.; Viejo, F.; Arrabal, R.; Matykina, E.; Corros. Sci. 2008, 50, 780.

2. Sugimoto, K.; Sawada, Y.; Corros. Sci. 1977, 17, 425.

3. Leygraf, C.; Hulquist, G.; Olefjord, I.; Elfstrom, B. O.; Knyazheva, V. M.; Plaskeyev, A. V.; Kolotyrkin, Y. M.; Corros. Sci. 1979, 19, 343.

4. Jargelius-Petterson, R. F. A.; Pound, B. G.; J. Electrochem. Soc. 1998, 145, 1462.

5. Scotto, V.; Ventura, G.; Traverso, E.; Corros. Sci. 1979, 19, 237.

6. Szklarska-Smialowska, Z.; Corrosion 1972, 18, 388.

7. Sedriks, A. J.; Corrosion of Stainless Steels; John Wiley \& Sons, Inc.: New York, USA, 1996, p. 105.

8. Lothongkum, G.; Vongbandit, P.; Nongluck, P.; Anti-Corros. Methods Mater. 2006, 53, 169.

9. Barbosa, M. A.; Corros. Sci. 1983, 23, 1293.

10. Refaey, S. A. M.; Taha, F.; Abd El-Malak, A. M.; Int. J. Electrochem. Sci. 2006, 1, 80.

11. Kelly, R. G.; Moran, P. J.; Corros. Sci. 1990, 30, 495.

12. Elsener, B.; Virtanen, S.; Boehni, H.; Electrochim Acta 1987, 32, 927.

13. De Anna, P. L.; Corros. Sci. 1985, 25, 43.

14. Ferreira, E. A.; Noce, R. D.; Fugivara, C. S.; Benedetti, A. V.; J. Electrochem. Soc. 2011, 132, 2854.

15 Pavia, D. L.; Lampman, G. M.; Kriz, G. S.; Engel, R. G.; Introduction to Organic Laboratory Techniques; Saunders College Publishing: Philadelphia, USA, 1998.

16. Boukamp, B. A.; Solid State Ionics 1986, 18, 136.

17. Song, G. L.; Corros. Sci. 2005, 47, 1953.

18. Stern, M.; J. Electrochem. Soc. 1959, 106, 376.

19. Olefjord, I.; Brox, B.; Jelvestam, U.; J. Electrochem. Soc. 1985 , 132, 2854.

20. Fattah-Alhosseini, A.; Saatchi, A.; Golozar, M. A.; Raeissi, K.; J. Appl. Electrochem. 2010, 40, 457.

21. Sato, N.; Corros. Sci. 1990, 31, 1.

22. Chao, C. Y.; Lin, L. F.; Macdonald, D. D.; J. Electrochem. Soc. 1981, 128, 1187.
23. Ferreira, E. A.; Rocha-Filho, R. C.; Biaggio, S. R.; Bocchi, N.; Corros. Sci. 2010, 52, 4058.

24. Sun, E. X.; Nowak, W. B.; Corros. Sci. 2001, 43, 1801.

25. Schultze, J. W.; Lohrengel, M. M.; Electrochim. Acta 1987, 45, 2499.

26. Schmidt, A. M.; Azambuja, D. S.; Martini, E. M. A.; Corros. Sci. 2006, 48, 2901.

27. Fattah-Alhosseini, A.; Golozar, M. A.; Saatchi, A.; Raeissi, K.; Corros. Sci. 2010, 52, 205.

28. Bojinov, M.; Fabricius, G.; Kinnunen, P.; Laitinen, T.; Mäkelä, K.; Saario, T.; Sundholm, G.; J. Electroanal. Chem. 2001, 504, 29.

29. Song, G. L.; Corros. Sci. 2005, 47, 1953.

30. Rao, V. S.; Singhal, L. K.; J. Mater. Sci. 2009, 44, 2327.

31. Wallinder, D.; Pan, J.; Leygraf, C.; Delblanc-Bauer, A.; Corros. Sci. 2000, 42, 1457.

32. Brooks, A. R.; Clayton, C. R.; Doss, K.; Lu, Y. C.; J. Electrochem. Soc. 1986, 133, 2459.

33. Barbucci, A.; Cerisola, G.; Cabot, P. L.; J. Electrochem. Soc. 2002, 149, B534.

34. Galleguillos, H. R.; Taboada, M. E.; Graber, T. A.; Bolado, S.; J. Chem. Eng. Data 2003, 48, 405.

35. Park, J. J.; Pyun, S. I.; Lee, W. J.; Kim, H. P.; Corrosion 1999, 55,380

36. Macdonald, J. R.; Impedance Spectroscopy - Emphasizing Solid Materials and Systems; John Wiley \& Sons, Inc.: New York, USA, 1987.

37. Orazem, M. E.; Tribollet, B.; Electrochemical Impedance Spectroscopy; John Wiley \& Sons, Inc.: New York, USA, 2008.

38. Goodlet, G.; Faty, S.; Cardoso, S.; Freitas, P. P.; Simoes, A. M. P.; Ferreira, M. G. S.; Belo, M. D.; Corros. Sci. 2004, 46, 1479.

39. Nicic, I.; Macdonald, D. D.; J. Nucl. Mater. 2008, 54, 379.

40. Morrison, S. R.; Electrochemistry of Semiconductor and Oxidized Metal Electrodes; Plenum Press: New York, USA, 1984.

41. Kocijan, A.; Donik, C.; Jenko, M.; Corros. Sci. 2007, 49, 2083.

Submitted: September 20, 2012

Published online: March 5, 2013

FAPESP has sponsored the publication of this article. 